\title{
HeTESI ERZSÉBET:" \\ A válság marketingje - marketing válsága? \\ A 21. század marketingkihívásai - lesznek-e válaszok?
}

\begin{abstract}
Absztrakt
A tanulmány arra keresi a választ, hogy abban az új világgazdasági helyzetben, amelyet a globális kihívások és a válság okoztak, milyen szerepe lehet a marketingnek. Röviden áttekinti a marketing krízishelyzetekböl való kilábalásának szakaszait, és felveti azokat a dilemmákat, amelyek a jövő marketingje számára egyelöre megválaszolhatatlanok. A tanulmány nem ad recepteket a kihívásokra, csak körvonalazza azokat a lehetőségeket, amelyek kiutat jelenthetnek a jövőben a marketing számára. A lehetséges kiutakat csak a klímaváltozás és a válság esetében elemzi.
\end{abstract}

\section{Bevezetés}

A marketing - kialakulása óta - többször került súlyos válságba. Az elmúlt néhány évtizeḍben számos drámai fordulatnak lehettünk tanúi - és akkor még nem is szóltunk a 20. század nagy váltásairól. Ezeket a válságos időszakokat a marketing mindig túlélte, mindig voltak jó, vagy kevésbé jó válaszai a kihívásokra, és azt mondhatjuk, hogy a marketing diszciplína nem veszített, hanem inkább nyert a megpróbáltatásokból. A marketing mára igazi tudománnyá vált, megalapozott paradigmákkal bír, professzionalizálódott, és önálló módszertana is van. Az elmúlt évek azonban olyan változásokat hoztak, amelyekre már nehéz lesz gyökeres paradigmaváltás nélkül gyümölcsöző válaszokat adni. A marketing többszörös szorításba került: a gazdasági növekedés ökológiai és társadalmi korlátjai miatt választ kell adni a fenntartható fejlödésre, a válság pedig arra is figyelmeztet, hogy a hagyományos, fogyasztásra ösztönző marketing stratégiák és eszközök megújulást kívánnak.

A tanulmány első részében röviden áttekintjük a marketing válaszait a krízishelyzetekben, majd megpróbáljuk felvázolni azokat a lehetöségeket, amelyekkel a jelenlegi többszörös szorításból a marketing úgy tud kikerülni, hogy megörzi pozícióját, és nem leírt vesztesként, hanem a kihívásokra adott kreatív válaszok következtében győztesként kerülhet ki.

\section{Kihivások és válaszok}

A marketing a századelőn a „semmiből” lett tudomány. Az AMA 1936-os megalakulását követöen mintegy berobbant az üzleti tudományok közé, és soha nem látott fejlődést mutatott. A 20. században sok-sok változást megélt, de mára mégis egy elfogadott és a gyakorlatban is jól kamatoztatható alkalmazott tudománnyá vált.

A marketing válságait a 20. század első kétharmadában a szakirodalom mélyrehatóan elemzi. Az értékesítési szemlélettöl a fogyasztó- és versenyorientált szemléleten át a testre szabott marketingig alapos elemzéseket találunk a változásokra vonatkozóan (GilmorePine 1997, Duray et al. 2000).

Az utóbbi három évtized azonban olyan mélyreható változásokat hozott a gazdasági

\footnotetext{
• Egyetemi docens - SZTE GTK Üzleti tudományok Intézete.
} 
életben, amelyek nem kerülték el a marketing tevékenységet meghatározó területeket sem. Felmerül a kérdés, hogy vajon a marketing ezeknek a változásoknak az elszenvedője, vagy éppen generálója?

\section{Mértöldkövek az elmúlt évtizedekben}

A szolgáltatásmarketing megjelenése élénk vitákat váltott ki a marketing szakemberek körében. A termékek többsége egyszerre szolgáltatás és tárgyiasult termék, és ma már egyre nehezebb tisztán tárgyi, illetve tisztán szolgáltatás jellegü terméket találni. Az 1970-es évek elején egyre több figyelmet kapott a szolgáltatásmarketing, mint a marketing egy önálló területe (Grönroos 1994, Pels et al. 2000), és egyre több vitát váltott ki az a kérdés, hogy vajon van-e létjogosultsága a szolgáltatások elkülönült marketingjének. Találkozhatunk a két területet önállóan kezelö, illetve a két témakört integráló véleménnyel is.

Lovelock szerint „A marketingmenedzsment feladatai két vetületben különböznek a termelöszférától. Az egyik a fizikai javak és a szolgáltatások közötti lényegi különbségböl származik, a másik pedig abból, hogy a marketingtervezés és végrehajtás... környezete más (Lovelock 1981). Mások azon a véleményen vannak, hogy „A fizikai és nem fizikai elemek minden termékben jelen vannak. Nem fizikai javakat vagy szolgáltatásokat értékesítünk..., (hanem) az elönyök egy olyan kombinációját, amely... fizikai és nem fizikai elemeket is tartalmaz." (Enis-Roening 1981). Engelhardt-Kleinaltenkamp-Reckenfelderbäumer (1993) szerint pedig „Az árucsere tárgyától függően mindig a klasszikus fizikai termékmarketing és a szolgáltatásmarketing keverékét alkalmazzuk." (in: Veres 2009. 26-32. o.).

Bár a szolgáltatások és tárgyiasult termékek marketingjének eltérését vizsgáló szakirodalom nem egységes, mégis azt mondhatjuk, hogy a szolgáltatások marketingje önálló diszciplínává vált, és a tevékenységek kiterjesztésével új dimenziókat is megtalálhatunk a marketing eszköztárban. Ezt a konfliktust sikeresen oldotta meg a marketing szakma.

$\mathrm{Az}$ utóbbi évtizedekben eröteljesebben jelent meg a fogyasztói és szervezeti piacok elkülöniulése. A marketinggel foglalkozók számára ma már közhelynek is tünik a kijelentés, hogy a fogyasztói piac és a szervezeti piac alapvetően eltér egymástól (Töröcsik 1996, Ford 2003, Kotler-Keller 2006). A két piac különbözőségei mindazonáltal lényegesen eltérö marketing gyakorlat kialakulását eredményezték. Míg a fogyasztási cikkek piacán az uralkodó megközelítés a tömegmarketing és a célpiaci marketing, addig a szervezetek piacán a vevök egyéni megkülönböztetése, a közvetlen marketing a leggyakrabban alkalmazott stratégia (Kotler 1992). Persze a marketing tevékenységek területén kizárólagosságról nem beszélhetünk, azt azonban a kutatások igazolják, hogy más az egyes megközelítések alkalmazásának gyakorisága a két terület esetén (Coviello et al. 2002) (in: Révész 2009). Létrejött a B2B marketinggel foglalkozók közössége (IMP) és számos könyv, cikk jelent meg ebben a témában.

Nagyon jelentös hatással volt a marketingre a technológia fejlödése is. A kutatási eredmények (az alapkutatások is persze, de sokkal inkább az alkalmazott kutatási eredmények) nagy hatást gyakorolnak a gazdasági életre, hiszen az újabb és újabb technológiák hatékonyabb megoldásokat kínálnak a gazdaság szereplöinek, aminek következtében javulhat a termelékenység. Napjainkban a menedzsment tudományok, s ezen belül a marketing területét leginkább átformáló fejlödés az információs technológia terén figyelhetö meg (Lindgreen et al. 2000, Pels et al. 2000, Sisodia-Wolfe 2000, Pels et al. 2004). Az egyre hatékonyabb, egyre inkább felhasználóbarát adatbázis és információmenedzsment (Holland-Naudé 2004), valamint a modern kommunikációs megoldások segítségével a marketing több részterülete vált hatékonyabbá, $s$ a fejlödés még nem állt meg. A vállalatok ma már könnyedén megismerhetik a vevők megrendelési, vásárlási szokásait, preferenciáit, és 
persze az egyes ügyfelek kiszolgálásából származó profit mértékét is, hogy aztán ezen információk birtokában tökéletesítsék kínálatukat, ajánlatokat fogalmazzanak meg ügyfeleik problémáinak megoldására, vagy éppen hatékonyabban juttassák el a vevők által igényelt terméket a rendeltetési helyére. Az információs technológia nélkülözhetetlen szerepet játszik a személyre-, ügyfélre szabott termékek, megoldások előállításában is, ezért egyre több szerző amellett érvel, hogy a marketing gyakorlatának megváltozásában elengedhetetlen szerepet töltött be az infokommunikációs technológia fejlődése (Grönroos 1996, Achrol-Kotler 1999, Lindgreen et al. 2000, Berry 2002) (in: Révész 2009).

A marketing számára kihívást jelentett az is, hogy egyre nagyobb lett a nem profitorientált szféra súlya, és meg kellett válaszolni azt is, hogy létezik-e nonbusiness szektor, vagy a nem profitorientált tevékenységek kizárólag a nonprofit szervezetekre vonatkoznak. A nonbusiness szektor elhatárolása meglehetősen bonyolult, sok az átfedés más szektorokkal, mégis, ha pontosítani akarjuk e szféra szervezeteit, akkor azt mondhatjuk, hogy ez a szektor ,al gazdasági élet azon szervezeteit tömöríti, amelyeknek fötevékenységét a kollektív igényeket kielégítő és/vagy közhasznú szolgáltatások képezik.. és ide sorolhatók a költségvetési, a közüzemi és a nonprofit szektor szervezetei." (Dinya et. al. 2004. 30. o.).

A nonbusiness szféra meglehetösen heterogén, és bár céljaik alapvetően nem ùzleti jellegüek, ahhoz, hogy fenn tudjanak maradni, és küldetésüket meg tudják valósítani, bevételt kell termelniük. Fennállásuk és hasznuk nem feltétlenül attól a nyereségtöl függ, amit termelnek, de valahol mégis szükségük van a piacorientált szemléletre, és így a marketing a nonbusiness szervezetek számára is egyre nagyobb jelentőséggel bír, hiszen az élesedő versenyben nekik is pénzt kell termelniük. Még az államilag támogatott szervezeteknek is bizonyítaniuk kell, hogy munkájuk miért hasznos a társadalom számára, és meg kell felelniük a vevői elvárásoknak. A fentiek alapján nyilvánvaló, hogy a különböző nonbusiness szervezetek gyakorlatában a marketingorientáció és a marketingmódszerek alkalmazhatósága eltérö. Ezzel kapcsolatban számos megválaszolatlan kérdéssel találkozhatunk:

- a ,nonbusiness” szektor sajátosságai mennyiben módosítják, korlátozzák a „,business” szektorban alkalmazott módszerek használhatóságát, adaptálási lehetőségeit?

- a „,nonbusiness” szektor sajátosságai indokolják-e speciálisan erre a szektorra érvényes marketing/menedzsment módszerek kidolgozását?

- a ,nonbusiness” szektor hazai fejlődésével lépést tart-e a szektor szereplőinek eredményes tevékenységéhez szükséges marketing/menedzsment módszerek kidolgozása, adaptálása, alkalmazása? (Dinya et al. 2004)

Ebben a kérdésben még a mai napig nem születetett egyetértés a szakmában, de számtalan külföldi és hazai tanulmány elemzi e szféra jellegzetes marketing specialitásait (AndreasenKotler 2006, Dinya et al, 2004, Pavluska 1999).

Új jelenség volt a nyolcvanas évektől a fogyasztók igényeinek növekedése, és sokkal inkább a fogyasztás megváltozott funkciója. A marketingeseknek azzal kellett szembenézniük, hogy az általuk központi kategóriaként kezelt fogyasztást már nem csak a szociológusok, de a pszichológusok is kutatják, és egészen új megközelítésekbe került a fogyasztás funkciója. A fogyasztó emberek azok, akik mind ez ideig többségükben úgy szocializálódtak, hogy az egyéni siker, a boldogság az anyagi javak birtoklásával, vásárlással, a fogyasztás növelésével érhető el és demonstrálható. A fogyasztásszociológiai tanulmányok széleskörüen foglalkoznak a fogyasztás megváltozott funkciójával. A legtöbb megközelítés szerint a modern társadalomban a fogyasztás társadalomszervező erővé lett, és a munkamegosztásban elfoglalt hely, a réteghez való tartozás fogyasztást determináló ereje megváltozott: ma sokkal inkább a fogyasztással demonstráljuk a hovatartozást, azaz a fogyasztás státuszt erősít, szociális identitást konstruál. A megkülönböztetés eszközeit Corrigan úgy közelíti meg, hogy a társadalmi pozíciók tere, és az életstílusok tere is egy térkép, és mi 
annak megfelelően helyezzük el az embereket a társadalmi- és életstílus térképeken, hogy miben különböznek egymástól. Minden egyes fogyasztási aktus reprodukálja a társadalmi különbségeket, de a kérdés az, hogy ,miért van, hogy bizonyos termékek fogyasztása jelzésértékünek tekinthetö a társadalmi megkülönböztetésben, míg más termékek fogyasztása nélkülözi a megkülönböztetö jelleget?"' (Corrigan 1997. 28. o.).

Az empirikus kutatásokban élen járnak George Ritzer vizsgálatai a gyorskiszolgáló éttermek sajátosságiról (a társadalom nálunk is gyakran emlegetett „mcdonaldizációjáról”), a kreditkártyák használatának következményeiröl és a fogyasztás új ,jelentéseiröl” (Ritzer 1995, 1996, 1999, 2003), de más szerzök munkáival is találkozhatunk a fenti témákban. A fogyasztói hitelekröl, mint az ,amerikai álmok finanszírozásáról” ír Lendol Caldler (Calder 1999), és figyelemre méltó Juliet Schor munkája is, aki a szabadidő nem várt csökkenését és a túlköltekezö Amerikát „Upscalling, Downshifting and the New Consumer” tanulmányában elemzi (Schor 1998).

A fenti kihívásokat még kezelte a marketing szakma, a 21. század elsö évtizedének második felében azonban mintha kumulálódnának a problémák. A gondok és kérdések komplexek, és olyan válaszokat igényelnek, amelyek alapjaiban kérdöjelezik meg a marketing korábbi gyakorlatát. A kihívások egyelöre dilemmákat vetnek fel, de ha a marketing szakma talpon akar maradni, akkor bizony ezekre a dilemmákra nagyon sürgősen megoldásokat kell találni.

\section{Vannak-e válaszok? Dilemmák a marketingben}

A következökben csak két olyan kritikus kérdésre keressük a választ, amelyek a marketinget új utak elé állítják, és amelyek megítélésünk szerint a közeljövöben paradigmaváltásokat eredményezhetnek a marketing szemléletben. A gazdasági és társadalmi változások több kérdést vetnek fel, de a tanulmány keretei arra adnak lehetöséget, hogy két kérdéskört elemezzünk: egyrészt a klímaváltozás hatását, másrészt a gazdasági, társadalmi válság hatását a marketingre.

\subsection{A klimaváltozás, a globális felmelegedés hatása a marketingre}

Az elmúlt mintegy 4 évtizedben számos tanulmány foglalkozott azokkal a káros jelenségekkel, amelyek a világot, ahol élünk veszélyeztetik. Úgy tünik azonban, hogy a marketing szakmát csak részben érintették meg ezek a kiáltványok, és igazi paradigmaváltásra nem került sor.

Tanulmányunk e részében ismertetjük azokat a mindennapi életünket és a föld jövöjét veszélyeztetö folyamatokat, amelyek marketing szempontból fontosak lehetnek (a klímaváltozás következményeit, a fogyasztói társadalom veszélyeit), és érintjük a fenntartható és a felelős fogyasztás kérdéseit. A pesszimista prognózisok elsösorban a földünket fenyegető ökológiai veszélyekre hívták fel a figyelmet, de látens módon a mára kialakult pénzügyigazdasági-társadalmi válságot is megjósolták.

Stern (2007) a klímaváltozás gazdasági hatásaira, illetve a szükséges intézkedésekre hívja fel a figyelmet. Megállapítja, hogy az éghajlatváltozás következtében jelentősen módosulni fognak az alapvetỏ életfeltételek, mint a víz, az élelmiszerek rendelkezésre állása, de befolyásolni fogja életünket az új betegségek feltünése is. Egysżerre lesznek tapasztalhatók szárazságok a világ egyes részein, míg más területeket pedig elfed a megemelkedö óceán. A jelentésböl az is kiderül, hogy ezek a károk a háborúk és válságok okozta károkkal szemben visszafordíthatatlanok lesznek, így nem lesz lehetőség az utólagos intézkedések meghozatalára. 
Turek (2005) szerint a fenntarthatóság és a fenntartható fejlődés kérdéskörét az 1970-es évektől kezdték mélyrehatóbban vizsgálni. A dokumentumban említést tesz többek között a Római Klub által publikált, Meadows és szerzőtársai (1972) nevéhez köthető „A növekedés határai" címü jelentésröl. Akkoriban meglehetősen pesszimistán látták a jövöt, a mai tapasztalataink alapján rövidebb ideig tartották folytathatónak az akkoriban jellemzö életmódot. 1972-ben került megrendezésre a Conference on Human Environment összejövetel, melyen a résztvevő fejlödő és fejlett országok megtárgyalták az ember környezete épségének fontosságát. A Konferencia eredménye az ENSZ Környezetvédelmi Programjának megalapítása lett. A fenntarthatóság, mint politikai célkitüzés az Egyesült Nemzetek Környezet és Fejlődés Világbizottsága által készített jelentésben fogalmazódott meg, melynek vezetője az akkori norvég miniszterelnök, Gro Harlem Brundtland volt. A Brundtland Bizottság jelentése alapozta meg a Rioi Konferenciát, amelynek célja a fejlödés és a környezetvédelem összhangjának megteremtéséhez szükséges intézkedések megállapítása volt. A Riói Konferencia (Earth Summit) eredményeként sziuletett meg az Egyesült Nemzetek Klímaváltozási Keretmegállapodása, melyet a gyakorlatban csak 1997. december 11-én fogadtak el Kiotóban, így az egyezmény közismertebb nevét is erről a városról kapta. Hatályba lépéséig azonban még kicsit több, mint hét évnek kellett eltelnie (2005. február Jelenleg 183 ország írta alá a megállapodást, azonban problémát jelent az, hogy az egyik legnagyobb környezetterheléssel rendelkező ország, az Egyesült Államok távolmaradt attól a gazdasági érdekeire hivatkozva. Az Európai Unió azonban példamutató módon jár elöl a környezet védelme terén.

\section{Mi a fenntartható fogyasztás?}

Ray C. Anderson, az Interface, Inc. alapítója és vezérigazgatója azt mondja: „Bünösök vagyunk, mindannyian bünösök vagyunk. El fog jönni az a nap, amikor a magunk fajták tetteikért börtönbe kerülnek" (Bakan 2004). Az általa képviselt szemlélet, melyet a Születés halála címü könyv olvasása kapcsán mond el a The Corporation címü filmben, tanulságos lehet minden vállalatvezető számára. A fenntarthatóság keresése szerinte tehát nem érdem, hanem kötelesség, melynek hiánya ma még nem büncselekmény, a jövőben viszont azzá válhat. Milyen tartalom húzódik meg e sokat használt fogalmak mögött?

A fenntartható fogyasztás egy sor társadalmi, gazdasági és politikai gyakorlatot ölel fel, melyek egyéni, családi, közösségi, üzleti és kormányzati szinten támogatják és erösítik a következőket:

1.A termelés környezetre gyakorolt hatásának csökkentése;

2.Az alapvető javak, mint az élelmiszerek, víz, egészségügy, oktatás és lakóhely elérhetőségének biztosítása;

3.A nők és gyermekek egészségét pozitívan befolyásoló termékek fogyasztása;

4.Energiahatékony berendezések, közlekedési eszközök (különösen tömegközlekedés)

- és egyéb kereslet-oldali tényezök kifejlesztése;

5.A globális környezeti korlátokat széles körüen figyelembe vevő termékek és termelési eljárások kialakítása;

6.A társadalmi összetartozást, a helyi hagyományokat és a nem anyagi értékeket jobban megbecsülö életstílus (Fien,J.http://www.unescobkk.org/fileadmin/user_upload/ esd/documents/workshops/kanchanburi/fien_tlsf.pdfRobins - Roberts 1998).

A fenntartható fejlödés, a klímaváltozás okozta új körülmények olyan válaszokat várnak a marketing tevékenység területén is, amelyek paradigmaváltást sürgetnek. 


\subsection{A válság hatása a marketingre}

Az elmúlt egy év hírei a válságról szóltak: elöször csak pénzügyi válságról, aztán gazdasági válságról, és úgy tünik ma már egyre inkább társadalmi válságról van szó. Smelser a stagnálás hatásairól írt tanulmányában részletesen ismerteti a gazdasági stagnálás politikai, kulturális és társadalmi hatásait (Smelser 1994). Megváltozik az értékrend, átrendezödik a szükségleti hierarchia, átalakul a fogyasztás struktúrája. Csökken az elosztható „torta" mérete, és megindul a harc a nagyobb szeletekért. Mindezek a változások nem hagyhatják érintetlenül a marketinget sem, ezekre a strukturális átrendeződésekre és ezen belül a fogyasztói attitüdváltozásokra szükséges lesz alkalmazkodással reagálni. A nemzetközi kutatások szerint a fogyasztók eltérö válaszokat adnak jövedelemcsökkenés esetén. Vannak, akik azonnal csökkentik fogyasztásukat. Mások nem tervezik fogyasztásuk csökkentését. Egy következő csoport később fogja fogyasztását visszafogni. Amire a kutatások felhívják a figyelmet, hogy a csoportok már nem határozhatók meg a hagyományos demográfiai szempontok szerint.

Megváltozik a szervezetek magatartása is: a csökkenö kereslet következtében csökken a jövedelmezöség, és nagyobb szerepet kap az árharc. A vállalatok költségcsökkentési kényszerei a termelés, a szolgáltatásnyújtás, az ár-és disztribúciós politika, valamint a promóciós tevékenység területén is megjelennek. Nem csak a megváltozott fogyasztói piaci körülményekhez, hanem a megváltozott szervezeti magatartáshoz is alkalmazkodnia kell a marketingnek. Ez a szervezetközi kapcsolatokat is érinti, így más megvilágításba kerülhet a kapcsolati lojalitás kérdése is, hiszen az árérzékenység nagyobb erövel jelentkezik. És a sort folytathatnánk. A tanulmány keretei nem teszik lehetövé, hogy a válság valamennyi marketingkövetkezményét felvillantsuk, de talán a fentïekböl is látható, hogy a kihivások komplexek, és időben egyszerre jelentkeznek.

\section{Milyen válaszokat adhat a marketing a kettós szoritásban?}

A következökben felvillantjuk azokat a lehetséges kiutakat, amelyek a marketing paradigmaváltásában szerepet játszhatnak, amelyek opcionális válaszok lehetnek a klímaváltozás és a globális válság kihívásaira. Ezek a felvetések a hektikus környezeti tényezők miatt semmiképpen nem tekinthetök használható javaslatoknak, csak egyszerü elmélkedések a kiutat illetöen.

\subsection{Piacszegmentáció, versenyanalízis, stratégiák}

A válság legfontosabb üzenete az, hogy a piacszegmentálási ismérvek valószínüleg alapjaiban megváltoznak. Az értékrendek, az attitüdök, a használati szokások változása a jövöben sokkal fontosabb lesz, mint a demográfiai tényezők, söt, a pszichológiai aspektusok elötérbe kerülése is várható. A válságnak nem csak a ténye, hanem a válságjelenségék kommunikálása is sokkolja a fogyasztókat, ami olyan változásokat okozhat a fogyasztói magatartásban, amelyek a marketing számára kiszámíthatatlanok. Éppen ezért újra kell gondolni a teljes szegmentációs politikát, és olyan új dimenziókat célszerü beemelni az ismérvek közé, amelyek mintegy „feltérképezik” a fogyasztók megváltozott szerepkörét. Egy 2009-ben végzett regionális empirikus vizsgálat eredményei azt jelezték, hogy a DélAlföldön a vagyoni státuszcsoportokat tekintve a megkérdezettek közel kétharmada átlagos, vagy átlag alatti szinten helyezkedik el (Veres et al. 2009). Már most is vannak próbálkozások arra vonatkozóan, hogy milyen hatásai lehetnek a vásárlói magatartásra a válságnak: 


\section{1. táblázat. A vásárlói magatartás változása}

A keresletcsökkenés kockázata

\begin{tabular}{|c|c|c|c|c|}
\hline & & A keresletcsökkenés kocká & & \\
\hline & Alacsony & & Magas & \\
\hline & $\begin{array}{c}\text { Alapvetö, } \\
\text { nélkülözhetetlen áruk }\end{array}$ & Megfontolandó termékek & Elhagyható termékek & 岕 \\
\hline $\begin{array}{l}\text { Napról napra } \\
\text { élök }\end{array}$ & $\begin{array}{l}\text { Olcsóbb termék/bolt } \\
\text { keresése, váltás ker. } \\
\text { márkákra, kisebb } \\
\text { tételek vásárlása }\end{array}$ & $\begin{array}{l}\text { Nem vagy csak szükség- } \\
\text { helyzetben, vagy jelentós } \\
\text { akció esetében vásárol }\end{array}$ & $\begin{array}{l}\text { Egyáltalán nem vásárol } \\
\text { ebben a kategóriában }\end{array}$ & 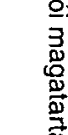 \\
\hline $\begin{array}{l}\text { Fájdalmasan } \\
\text { túlélök }\end{array}$ & $\begin{array}{l}\text { Márkahüség csök- } \\
\text { ken, váltás olcsóbb } \\
\text { alternativákra }\end{array}$ & $\begin{array}{l}\text { Értékösszehasonlitás, } \\
\text { vásárlás elhalasztása, } \\
\text { akciók keresése }\end{array}$ & $\begin{array}{l}\text { Nem vagy csak szük- } \\
\text { séghelyzetben, vagy } \\
\text { jelentös akció esetében } \\
\text { vásárol }\end{array}$ & 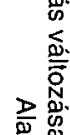 \\
\hline $\begin{array}{l}\text { Kényelmesen } \\
\text { túlélök }\end{array}$ & $\begin{array}{l}\text { Folytatja a megszo- } \\
\text { kott márkák vásárlá- } \\
\text { sát }\end{array}$ & $\begin{array}{l}\text { Folytatja, de igényesebbé } \\
\text { válik }\end{array}$ & $\begin{array}{l}\text { Nem szünteti meg a } \\
\text { vásárlást, igénye nó, a } \\
\text { legkirivóbbaktól eltekint }\end{array}$ & $\stackrel{8}{\stackrel{8}{\circ}}$ \\
\hline
\end{tabular}

Forrás: Rekettye, 2009 HBR, April, 2009, Quelch and Jocz alapján

Úgy tủnik, hogy a hagyományos versenyanalízis analitikája is megújulást követel. A szervezetek viselkedése is más stagnálás esetén, megváltoznak az ágazati jellemzők, átalakulnak az ágazati magatartások. Ez arra figyelmeztet, hogy a B2B marketingnek is érdemes „,válságmegoldásokat”keresnie: meg kell találnia azokat az eszközöket, amelyek az árérzékenység növekedése ellenére is fokozzák a lojalitást, sokkal nagyobb hangsúlyt kell fektetni az ágazati sajátosságok elemzésére, az ágazatok közötti átrendeződések következményeinek marketinghatásaira.

Célszerü újragondolni a különböző pozícióban lévő szervezeteknek a korábbi stratégiájukat: érdemes-e küzdeni kihívóként a piacvezető pozícióért, mennyit ér ez meg, illetve milyen veszteségek lehetnek, ha nem sikerül a harc? Egészen biztos, hogy a piac átrendeződése új piaci réseket nyit majd meg, és ezeket is célszerü felmérni. A klímaváltozás következményeire való reagálás lehet a jövöben a szervezetek egyfajta strukturáló tényezője, és ebben valószínüleg nagy szerepe lesz a CSR-nek. Már az elmúlt években is új elemekkel gazdagodtak a felelős vállalkozói magatartás irányába ható erők, amelyeket a vállalkozásoknak érdemes nyomon követniük. Ugyanis, ha továbbra is versenyképesek akarnak maradni, akkor ajánlatos alkalmazkodniuk a piac és az őket körülvevő társadalom új igényeihez, így például a vevők részéről megnyilvánuló, folyamatosan erösödő újfajta nyomáshoz.

\subsection{A marketingkutatások módszereinek és irányultságának változási szükségessége}

A megváltozott körülmények közötti eligazodás nem nélkülözheti a hiteles, naprakész, megbízható információkat. Éppen ezért a jövőben a marketingnek a korábbiaknál is nagyobb mértékben kell támaszkodnia a kutatási eredményekre, ami feltehetöen felértékeli majd a piac, marketing- és közvéleménykutatás jelentöségét. A változások mind a fogyasztók, mind a szervezetek magatartását oly mértékben módosíthatják, amelyek megismerése nélkül nem születhetnek felelős döntések, és bár a költségcsökkentések általában a kutatási buidzséket érintik elsőként, ezt a vezetői attitűdöt a jelenlegi helyzetben el kell felejteni. A kutatási módszerek és azok irányultsága kapcsán át kell gondolni, hogy milyen változtatások szükségesek: úgy gondoljuk, hogy a kvantitatív - és föként online - kutatások „tiszavirágéletü" korszaka ebben a helyzetben nem elönyös információszerzési módszer. A globális kihívások és válság pszichológiai hatásai újra előtérbe helyezik majd a kvalitatív, minőségi információkat eredményezỏ módszereket. 
A kutatási területek, témák, problémák is megváltozhatnak: a fogyasztói piacokon inkább az attitüdök, magatartások vizsgálata kerülhet előtérbe, míg a B2B piacokon a lojalitás, bizalom, elkötelezettség kérdései válnak majd fontossá.

\section{4. És akkor hogyan kezeljük a klasszikus 4P-ét, a „posztmodern" 7P-ét?}

A fentiek után talán nem meglepö, ha úgy gondoljuk, hogy a „kőbevésett” P-ék is paradigmaváltást követelnek az ú helyzetben.

\subsection{Hogyan tovább a termékpolitikával és az innovációval?}

A jövöben a termék nem lehet az identitást konstruáló, társadalmi státuszt erösítő tényezö, a terméknek vissza kell nyernie eredeti, szükségletkielégítő funkcióját. A fogyasztókat arra kell ösztönözni, hogy a fenntartható fejlödés érdekében ne a „pazarlás váljék illendövé, és az illendö szükségessé..." (McKendrick et al. 1982), hanem a fogyasztásunkban tudjunk mértéktartóak lenni. Erre a racionalitásra kell a termékpolitikának felhívni a fogyasztók figyelmét, és ez mind az innovációban, mind a termékválaszték politikában gyökeres változásokat igényel. A portfóliót nem bővíteni, hanem racionálisan szükíteni kellene, és ebben a szükítésben iránytüként szolgálhatna egy olyan elv, amely szerint nem az a cél, hogy a szükségletet különleges módon elégítsük ki, hanem hogy valahogy kielégítsük. Megfontolandó az is, hogy az innováció ne legyen az értelmetlen differenciálás (pl. a használatot gátló öncélú formatervezések), hanem inkább törekedjen arra a termékfejlesztés, hogy a cél ne az identitást erősítő termékfunkciók innovációja legyen, hanem sokkal inkább az egyszerü, praktikus, kényelmes szükségletkielégítés. A termékpolitikában újra kellene gondolni a márkázás szerepét is. A márkatudat, a márkaközösségek üzenjék inkább a fenntarthatóságot, mint a kirívóságot, az értelmetlen megkülönböztetést váltsa fel a racionalitás, a pozicionálásban pedig a hivalkodást az egyszerüség (Miller 1987). Ami pedig az életciklus-elemzéseket illeti, ott az lenne a racionális, ha nem arra törekednének a szervezetek, hogy szeszélygörbékkel hirtelen meggazdagodjanak, hanem inkább arra, hogy stílusgörbékre törekedjenek és hosszabb távon is piacon tudjanak maradni termékeikkel, szolgáltatásaikkal.

A termékpolitikát nem csak a klímaváltozás és a válság, hanem a növekedés társadalmi korlátai is megújulásra kényszerítik a marketingben. Amikor Fred Hirsch (1976) a gazdasági növekedés társadalmi korlátjait elemezi, arra hívja fel a figyelmet, hogy a modern társadalmakban egyre több termék válik pozicionális termékké, amelyek funkciója nem a szükséglet kielégítése, hanem a társadalmi státusz demonstrálása, és amely termékek másolásának idötartama egyre rövidebb, így demonstráló erejük is halványul. Egyre kevésbé tudunk már olyan termékeket elöállítani, amelyek megkülönböztetnek másoktól, így inkább korlátozzuk a megkülönböztető termékek mennyiségét, és ez a növekedés társadalmi korlátjává válik (Hirsch 1976). További korlátként jelentkezik az a tény, hogy egyre több termék kommercializálódik, a kereskedelem tárgyává válnak olyan javak, mint a víz, a levegö, az interneten vásárolható gyermek. Mit tud tenni ez ellen a marketing?

\section{2. Új alapokon az ármarketing?}

Újra kell gondolni az árpolitikai marketing tevékenységet is. Az ár minöségüzenete, az áralkalmazások és az differenciálások gyakorlata is változtatásokat sürget. Az ár nem lehet a továbbiakban fogyasztót ,ingerlö" tényező, az árnak inkább a megtakarító szerepét kell hangsúlyozni. Különösen igaz ez a szolgáltatásokra, ahol az ár intranszparens tényezö, és a 
fogyasztó nem igazán tudja megítélni az árak realitását. Az önmegtartóztató magatartás az árpolitikában a szolgáltatások területén azért is indokolt, mert azok aránya a GDP-ben lassan eléri a négyötödöt a világ számos országában. Ugyanakkor az árcsökkentés nem biztos, hogy mindig jó stratégia, a jó márkáknál célravezetöbb lehet az értékcentrikus árpolitika. Az árversenybe így is a nagyobb tartalékokkal rendelkező szervezetek lehetnek sikeresek. Az ármarketingben az értéklánc felülvizsgálata és minden lehetséges árnövelő tényező kiiktatása is szuikséges, de át kell gondolni az áralkalmazások tárát is. A promóciós, az engedményes és a megkülönböztető árak esetében nagyobb szerepet kaphat a megkülönböztetö árak alkalmazása a szegmentációs ismérvek alapján.

\subsection{Biztos, hogy hatékonyak a jelenlegi disztribúciós utak?}

Az elosztási csatornák arzenálját szükíteni kell, és meg kell találni a költségkímélő módszereket. Azok az új értékesítési módok, amelyek elönyöket ígérnek, de igazából energiaráfordításokat vesznek igénybe (pl. multilevel értékesítés, személyes találkozásokon ígéretek tömkelege) ki kell hogy kerüljenek az értékesítési csatornákból. Olyan disztribúciót kell támogatnia a marketingnek, ami a fogyasztó számára gazdaságos, és könnyen elérhető. Szükség lesz a supply chain korszerüsítésére, a csatornák szükítésére, a fogyasztói mozgások fokozottabb követésére. A kiskereskedelem átrendezödése is várható, és valószínüleg megnő a kereskedelmi márkák térnyerése is az elosztásban (Rekettye 2009). Már most látható a fogyasztók mozgása az alacsonyabb árfekvésü kereskedelmi egységek felé, és ha a válság elhúzódik, akkor ez a tendencia tovább erösödhet.

\subsection{A promóciós tevékenység átalakulása}

A promóciós tevékenység a legérzékenyebb pontja a paradigmaváltásnak. A kérdés az, hogy a recesszió okozta bizalmatlan helyzetben miként változik a cégek kommunikációja, valamint, hogy a fogyasztói szokások változása milyen hatással van a marketingszakmára. Ha a gazdasági válság okait kellene elemezni, a különböző okok között biztosan megtalálnánk a reklámkommunikációt, mint okolható tényezőt. A vásárlók befolyásolásában mindig is komoly szerephez jutott a reklám. Az üzenetek többsége mindeddig azt sugallta, hogy képesek lehetünk egy olyan életforma elérésére, amelyhez nyilvánvalóan csak a bankok támogatásával juthatunk el. A reklámok folyamatosan egy olyan világot vetítenek elénk, amely elérésére nem sokunknak van lehetősége. De vajon miként változik az u̇zenetek tartalma válságos időszakban?. Sok forgatókönyv létezik arra az esetre, amikor receszszió hatására a cégnek át kell hangolnia, vagy akár teljes mértékben meg kell változtatnia a marketing stratégiáját a fennmaradás érdekében. Biztosan állítható, hogy ebben az idöszakban a cégeknek még több figyelmet kell fordítaniuk a vásárlóik változó igényeire és ehhez mérten kell átalakítaniuk marketing-kommunikációjukat. Manapság azok a márkák lehetnek sikeresek, amelyek érzelmi kapcsolatot tudnak kialakítani vevőikkel. Ezért nagyon fontos a kommunikáció szerepe és jellege, különösen akkor, amikor a vásárlói rétegek teljesen átrendeződnek a recesszió hatására (ifj. Rekettye 2009). A promócióban minden területen a marketing társadalmi felelősségét kell hangsúlyozni, és kerülni kell a fogyasztókat megtévesztő, manipuláló üzeneteket. A promócióban nagyobb hangsúlyt kell fektetni a PR tevékenységre, és feledni kell az olyan reklámokat, eladásösztönzési akciókat, amelyek megtévesztik a fogyasztókat, és irracionális döntésekre inspirálják öket. A CSR, a szponzorálás és az ügymarketing valószínüleg felértékelődnek a jövőben, így a kommunikációs mix arányai megváltoznak, és hangsúlyosabbá válik majd az integrált kommunikáció. Várható a reklámeszközök átrendeződése is, a hagyományos eszközök (tv, 
rádió, kültéri) feltehetően visszaszorulnak, és nő a digitális és gerillamarketing szerepe (Rekettye 2009). A promóció tehát az egyik leginkább sérülékeny pontja a marketingnek, ahol minden valószínüség szerint a legnagyobb változások mennek majd végbe a klímaváltozás és a válság hatására.

\subsection{Mi lesz a szolgáltatások 3P-jével?}

Minden jel szerint a szolgáltatásmarketing is gyökereiben változik meg majd a jövöben. A kettős szorítás nem hagyja érintetlenül a frontvonal-menedzsment tevékenységeit, és változásokat sürget a folyamatok és a fizikai kömyezeti elemek stratégiáiban is. Biztosan kevesebb energiát kell majd fordítani a fizikai környezet elemeire, és a hangsúly eltolódik az emberi tényezỏ és a folyamatok szabályozása felé. Nagyobb szerepet kaphat a jövőben a panaszok kezelése, az ügyfelek bevonása a folyamatokba, a kapcsolatiság erősítése, és különösen fontossá válhat a fogyasztói lojalitás növelése a bizalom, az elkötelezettség, a szervezeti értékekkel való azonosuláson keresztül. Itt találkozhat a hatékony marketingkommunikáció, és a kapcsolati marketing. Olyan helyzetekben, amikor sokkal inkább a fogyasztó érzelmi kötődése a fontos, a kapcsolatok ápolása rendkívüli jelentőséggel bírhat.

\section{A marketing kierjesztése - a társadalmi marketing}

A marketing már korábban is hajlandóságot mutatott arra, hogy a fenti kihívásokra választ adjon. Jó példa erre a marketing kiterjesztő felfogása, a társadalmi marketing eröteljes térnyerése. A marketingszemlélet kiterjesztése a nem üzleti szervezetekre is, ami Kotler és Levy (1969) cikkének alapgondolata, talán több volt, mint újszerü, szinte forradalminak számított az akkori közegben. A társadalmi marketing hívei a marketing helyének és szerepének újragondolása mellett törnek lándzsát. A klímaváltozás a globális problémák tovább erősítik azt a tényt, hogy a jövőben nagyobb hangsúlyt kell helyezni a társadalmi marketingre. Sajnos a társadalmi marketing aránya a marketing gyakorlatában és a marketingelméletben a vállalati marketinghez képest ma még elenyésző. Ha a téma elméleti oldalát nézzük, akkor megállapíthatjuk, hogy ma még a társadalmi marketing fogalma sem egyértelmü az elméletben. Sokan, még az angolszász szakirodalomban is, összemossák a társadalmi marketinget (social marketing) a társadalmi célú marketinggel (societal marketing) (Peattie \& Peattie, 2003, McDermott et al., 2005, etc.) (in: Rekettye-ifj. Rekettye 2009).

Ebben az új helyzetben szükség lesz a társadalmi marketing definiálására és eszközrendszerének kidolgozására. Olyan paradigmaváltásról van szó, ahol a klasszikus marketingfelfogás helyett egy olyan típusú marketingre van igény, amely nem a fogyasztás értelmetlen ösztönzését, hanem a racionális, a fenntartható fejlödést segítő fogyasztási struktúrát preferálja. Bár a marketing fogyasztáscsökkentésre irányuló törekvése meglehetösen ellentmondásosnak tünhet, a kihívásokra nem lehet más válasz, és ez teljesen új megközelítést igényel (Rekettye-ifj. Rekettye 2009).

\section{Összegzés}

Akkor mit is mondhatunk a jelenlegi helyzetben a marketing jövőjéröl? Azt, hogy a marketing újra válságba került, és a válsággal, a globális kihívásokkal szemben csak akkor kerülhet ki gyöztes diszciplínaként, ha képes lesz gyökeres paradigmaváltásra, ha elfogadja azt, hogy a föld jövője és a válság vesztesei új paradigmákat követelnek. Azt mondhatjuk, 
hogy át kell gondolnunk jó-e az, amit eddig csináltunk? Mit tett a marketing a fogyasztásra való ösztönzéssel a föld jövöje érdekében, mit tett a marketing a fogyasztásra való ösztönzéssel a pénzügyi válság megakadályozásáért? Azt mondhatjuk, hogy a marketingben megújulásra van szükség, és azt is, hogy a korábbi gyakorlathoz való ragaszkodás, a rugalmatlanság a marketing vesztét jelentheti, és hogy kreativitásra, másfajta innovációs szemléletre, felelősségvállalásra, gyökeres paradigmaváltásra van szükség.

Ehhez azonban az kell, hogy a szakma elméleti és gyakorlati művelöi egy emberként gondolkodjanak, és egy emberként akarják a legjobbat kihozni a marketing jövőjéből!

\section{Irodalomjegyzék}

Achrol, R. S.-Kotler, P. (1999): Marketing in the network economy, Journal of Marketing, Vol. 63, special issue, pp. 146-163.

Bakan, J. (2004): The Corporation - Beteges hajsza a pénz és a hatalom után. Független Média Kiadó, Budapest.

Berry, L. L. (2002): Relationship Marketing of Services-Perspectives from 1983 and 2000, Journal of Relationship Marketing Vol. 1, n. 1, pp. 59-94.

Brundtland, G. H. (1987): Our Common Future, Oxford University Press, Oxford.

Calder, L. (1999): Financing the American Dream: A Cultural History of Consumer Credit Princeton, NJ: Princeton University Press.

Corrigan, P. (1997): The Sociology of Consumption, Sage, London.

Coviello, N. E.-Brodie, R. J.-Danaher, P. J.-Johnston, W. J. (2002): How Firms Relate to Their Markets: An Empirical Examination of Contemporary Marketing Practices, Journal of Marketing Vol. 66, N. 3, 33-46. p.

Dinya L.-Farkas F.-Hetesi E.-Veres Z. (2004): Non-business marketing és menedzsment. KJKKerszöv, Budapest.

Duray R.-Ward P. T.-Milligan G. W.-Berry W. L. (2000): Approaches to mass customization: configurations and empirical validation, Journal of Operations Management, Vol. 18, No. 6, pp 605-625.

Fien, J.: Teaching and Learning for a Sustainable Future, UNESCO, New York http://www.unescobkk.org/ fileadmin/user_upload/esd/documents/workshops/kanchanburi/fien_tlsf.pdf

Ford, D. (2003): Business marketing, KJK Kiadó, Budapest.

Gilmore, J. H.-Pine, B. J. (1997): The Four Faces of Mass Customization, Harvard Business Review Vol. 75 No. 1, pp. 91-101.

Grönroos, C. (1996): Relationship marketing: strategic and tactical implications, Management Decision, Vol 34, N. 3, 5-14. p.

Hirsch, F. (1976): Social Limits to Growth, Harvard University Press, Cambridge, 208 s. Den benyttede udgave er fra Routledge \& Kegan Paul, London.

Holland, C. P.-Naude, P. (2004): "The Metamorphosis of Marketing into an Information-Handling Problem", Journal of Business and Industrial Marketing, vol. 19(3), pp. 167-177.

Ifj. Rekettye, G. (2009): A gazdasági válság hatásai a reklámkommunikációra. MOK. 15. Jubileumi Országos Konferenciája,"Új marketing kihívások a XXI. században - Fenntartható fogyasztás", Kaposvár, 2009. augusztus 25-26. CD.

Kotler, P.-Keller, K. L. (2006): Marketingmenedzsment, Akadémiai Kiadó, Budapest.

Kotler, $P$. (1992): Marketingmenedzsment, Müszaki Könyvkiadó, Budapest.

Kotler. P.S. J. Levy (1969): „Broadening the Concept of Marketing”, Journal of Marketing, 33 January, pp. 10-15.

Kotler. P.-A. R Andreasen (2006): Books.Strategic Marketing for NonProfit Organizations (5th Edition) (9780132325479).

Lindgreen, A.-Davis, R.-Brodie, R. J.-Buchanan-Oliver, M. (2000): Pluralism in contemporary marketing practices, International Journal of Bank Marketing, Vol. 18, N. 6, 294-308. p.

McDermott, L.-Stead, M.-Hastings, G. (2005): What Is and What Is Not Social Marketing: The Challenge of Reviewing the Evidence, Journal of Marketing Management, 21, 5, pp. 545-553. 
McKendrick-Neil-Brewer-John and Plumb, J. H. (1982): The Vrith of a consumer Society: The Commercialization of Eigh-teenth-Century England. London.

Meadows, D.-Randers, J.-Meadows, D. (1972): The Limits To Growth, Thirty Years Later. http://www.chelseagreen.com/

Miller, D. (1987): Material Culture and Mass Consumption. Oxford, Basil Blackwell, pp. 240.

Pavluska, V. (1999): A nonprofit szektor. (Humán szervezö [munkaügyi] menedzser sorozat) Pécs: JPTE FEEFI, 1999. 216 p. ISSN: 0866-627X

Peattie, K.-Peattie, S. (2008): Social marketing: A pathway to consumption reduction? J Bus Res, doi: $10.1016 / j$. Journal of Business Research.

Pels, J.-Brodie, R. J.-Johnston, W. J. (2004): Benchmarking business-to-business marketing practices in emerging and developed economies: Argentina compared to the USA and New Zealand, Journal of Business \& Industrial Marketing Vol. 19 N. 6, 386-396. p.

Pels, J.-Coviello, N. E.-Brodie, R. J. (2000): Integrating transactional and relational marketing exchange: a pluralistic perspective, Journal of Marketing Theory and Practice, Vol. 8, N. 3, 1120. p.

Reketrye G. (2009): Marketing a recesszió időszakában. MOK. 15. Jubileumi Országos Konferenciája, „Ưj marketing kihívások a XXI. században - Fenntartható fogyasztás”, Kaposvár, 2009. augusztus $25-26 . \mathrm{CD}$.

Rekettye. G.-ifj. Rekettye G. (2009): A világjövöje - a jövö marketingje. Vezetéstudomány, XXXX. évf. 2. szám, pp. 2-9.

Révész B. (2009): A kapcsolatorientáció marketing jelentösége. Kézirat, SZTE GTK.

Ritzer, G. (1995): Expressing America: A Critique of the Global Credit Card Society. Thousand Oaks, Pine Forge Press, CA.

Ritzer, G. (1996): The McDonaldization of Society. Thousand Oaks, Pine Forge Press, CA.

Ritzer, G. (1999): Enchanting a Disenchanted World: Revolutionizing the Means of Consumption. Thousand Oaks, Pine Forge Press, CA.

Ritzer, G. (2003): Consumers, Commodities, and Consumption, Prospective American Sociological Association ASA, Section - information.

Schor J. B. (1998): The Overspent American. Upscalling, Downshifting, and the New Consumer. New York, Basic Books.

Sisodia, R. S.-Wolfe, D. B. (2000): Information Technology: Its role in building, maintaining, and enhancing relationships, in Sheth, J. N. - Parvatiyar, A. (ed): Handbook of Relationship Marketing, SAGE, Thousand Oaks.

Smelser, Neil J. (2008): Economic stagnation and its interrelation with the societal order.

Steger, U. Perspectives for Corporate Social Responsibility, IMD, May, Working Paper.

Stern, N. (2007.): Stern-jelentés - Az éghajlatváltozás közgazdaságtana, http://www.rec.hu/ Dokumentumok/STERNosszefoglalo.pdf

Töröcsik, M. (1996): Ipari marketing, Nemzeti Tankönyvkiadó, Budapest.

Turek, J. (2005.): A History of Sustainability, http://www.cap-Imu.de/fgz/portals/sustainability/ history.php

Veres Z.-Hetesi E.-Andics J. (2009): Életstílus, szabadidő struktúra és márkapreferenciák. MOK. 15. Jubileumi Országos Konferenciája, „Új marketing kihívások a XXI. században - Fenntartható fogyasztás", Kaposvár, 2009. augusztus 25-26. CD.

Veres. Z. (2009): A szolgáltatásmarketing alapkönyve. Akadémiai Kiadó, Budapest, 578 p. 